\title{
WOMEN LEADERSHIP AND POLITICAL PARTICIPATION IN AFRICA (A STUDY OF NIGERIA AND GHANA)
}

\author{
Okonkwo Denisia Ijeoma \\ Department of Political Science and International Relations/Faculty of Management and \\ Social Sciences, Godfrey Okoye University Ugwomu-Nike, Enugu
}

Email: odenisia2000@gmail.com

Cite this article:

Okonkwo D.I. (2022), Women Leadership and Political Participation in Africa (A Study of Nigeria and Ghana). African Journal of Social Sciences and Humanities Research 5(1), 19-24. DOI: 10.52589/AJSSHRQLXSVCL9

\section{Manuscript History}

Received: 27 Dec 2021

Accepted: 25 Jan 2022

Published: 3 Feb 2022

Copyright $\left({ }^{\circ} 2022\right.$ The Author(s). This is an Open Access article distributed under the terms of Creative Commons AttributionNonCommercial-NoDerivatives 4.0 International (CC BY-NC-ND 4.0 ), which permits anyone to share, use, reproduce and redistribute in any medium, provided the original author and source are credited.
ABSTRACT: This study carried out an empirical analysis of women leadership and political participation in Africa with an empirical focus in Nigeria and Ghana. Data for the study were generated through secondary sources which includes Worldbank, World Development Index (WDI) and Political Reports (PR). The methodology used in the study is a documentary comparative analysis. The theoretical framework employed for this study is Kanter's "Glass-Ceiling Theory" (1977). The major findings of the study is that despite the relevance of women in the politics of Africa, women in this continent are still grossly underrepresented. It is worth noting that Ghanaian and Nigerian women are still disenfranchised as a result of the country's leadership style. It is therefore the recommendation of this study that political parties in Nigeria and Ghana should establish a support network for aspiring female politicians by pairing them with experienced female politicians who will serve as mentors and provide capacity building for young or aspiring female politicians in order to enhance and develop them ahead of future elections and secondly, to develop an environment that empowers African women to participate actively in decision-making in a sustainable and effective manner that is free of all forms of violence and harassment.

KEYWORDS: Women Leadership, Political Participation, Political Reports, Women in the Politics, Nigeria, Ghana 


\section{INTRODUCTION}

One of the defining or essential developments of contemporary times has been the global drive toward gender equality. Today's media debates are centred on achieving equity and justice for all people, especially women. Due to the minimal engagement of women in leadership, politics and government, women's rights problems have attracted the attention of policymakers, experts, and civil society organizations (Hamah, 2015).

Leadership, particularly political leadership, is critical to any nation's success. Any country's progress, development, and fortunes are dependent on the type and quality of political leadership it has had and continues to have. Leadership, like other processes, is, nonetheless, gendered. Institutional leadership is gendered, just as institutionalized practices and the institutional structures themselves (Moshood, et al, 2019). Within hierarchies that favour men over women, certain processes, practices, structures, and institutions exist. Women and men who pass through these institutions and procedures do so as a lived experience, taking with them all of their traits (e.g., sex, class, education), beliefs, and life lessons learned through their own bodies.

As a result, women and men seeking political leadership must contend with institutionalized gender dominance, which moulds and structures their lived experience of leadership. Each reality is more than a matter of personal preference or discrimination. It's a result of established gender structures. As a result, women and men have distinct experiences as a result of this. Because their variety and life experiences impact their leadership, not all women and men have the same experiences (Aluko, 2011). Historically, women have been excluded from governmental organizations that define political and legislative agendas. When compared to the low rates of female political representation in the 1960s, Africa has seen a rapid increase in female political representation in recent years. Women's participation in decision-making is becoming increasingly important on the global agenda (Ndlovu \& Mutale, 2013).

Confirmatory changes in African governance, aided by the continent's growing democratic consolidation, have increased women's political engagement. Various laws, programs, and projects are in place to promote gender equality and women's empowerment, and numerous achievements have been recorded in the advancement of gender equality and women's empowerment. Although African women have achieved considerable progress in terms of political engagement around the world, a huge gap still exists. Women have a monumental challenge before being recognized as complete equals and partners to their male counterparts.

The adoption of the United Nations Sustainable Development Goals (SDGs) is currently providing worldwide support for the fight to secure political leadership and participation for women. These are seventeen goals that address environmental, social, and economic concerns, with a deadline of 2030. SDG 5 focuses on promoting and achieving gender equity and equality, women's empowerment, and ensuring effective and active representation, equitable participation, and leadership opportunities for women in economic, public, and political decision-making processes (Desa, 2016).

The third wave of the international women's movement, which began in the 1990s, expanded the scope of women's action to include the demand for greater political representation for women (Paxton et al, 2006; Heywood 2011). It is founded on the premise that the realization of women's equal right to vote, right to property ownership, and general 
emancipation from patriarchal contexts is primarily contingent on satisfactory women's participation in decision-making processes. Women's groups in various parts of the world have intensified their campaign for national policies and legislation that would allow for gender quotas in order to achieve the ultimate goal of establishing more political space for women (Childs \& Krook 2008).

Apparently, in this broad struggle for women's political emancipation, women in Nigeria and Ghana are not left out. Especially since the opening of democratic windows towards the end of the 20th century, Nigerian and Ghanaian women are noted for initiating clamour for positive action that could break the barriers obstructing their adequate political presence in government. Yet, unlike the cases of other African states, where quotas laws have already become a successful story, there is less scholarly work on the patterns of such movement as well as its precipitating factors in Nigeria and Ghana, either specifically or comparatively. This is notwithstanding the fact that both countries are leading Anglophone states in West Africa with respect to population and women's activism. Against this background, the present article examines the comparative nature of women leadership and political participation in Africa with an empirical focus on Nigeria and Ghana.

\section{LITERATURE REVIEW}

Adeleke (2014) carried out an empirical study on women's political participation at the local government level in Nigeria. In the course of the study, fieldwork was conducted in relation to the importance of women's political participation at the grassroots, factors hindering women's political participation, and measures that can enhance women's political participation, in Oka and Akungba in Akoko South-West Local Government Area of Ondo State Nigeria. One hundred and eighty (180) copies of the questionnaire were administered to randomly selected respondents, and the study shows that women can gain more political experience at the local level; thus enhancing their effectiveness at a higher level of decision-making, if given a chance. The study also identifies factors hindering women's local political participation, most especially patriarchy.

Innocent (2020) examined online advocacy campaigns by five women action groups in Nigeria and Ghana. Based on modern social movement theories, the study utilizes computer-mediated discourse analysis to qualitatively analyze the content of the websites and social media platforms of these groups. Findings show that social media provide women advocacy groups with a voice that tends to defy intimidation and the traditional patriarchal stereotypes to demand the rights of women to political leadership. Discourse structures of protest discourses include imperative statements or direct acts that demand change by all means. Through online activism, the advocacy groups extend their voices, and activities to reach national and international audiences and communities of people - also reaching out to the most vulnerable rural women and the underprivileged. However, only a small percentage of women in rural areas have access to the Internet, thereby limiting participation in online activism in cities and urban centres.

\section{Trend Analysis of Women Participation in Politics in Africa}

Women's equal and effective participation in political decision-making is still a long way off in Africa. Women make up only 24\% of Africa's 12,113 lawmakers, 25\% in the lower chambers and $20 \%$ in the higher houses. While local government is often hailed as a training ground for 
women in politics, women constitute a mere 21 percent of councillors in the 19 countries for which complete data could be obtained (Africa-Barometer, 2021). These are some of the key findings from Gender Links and the International Institute for Democracy and Electoral Assistance's Africa Barometer 2021. (International IDEA). The Barometer is an important resource for the International IDEA-led consortium: Increasing Women's Political Participation in Africa (WPP).

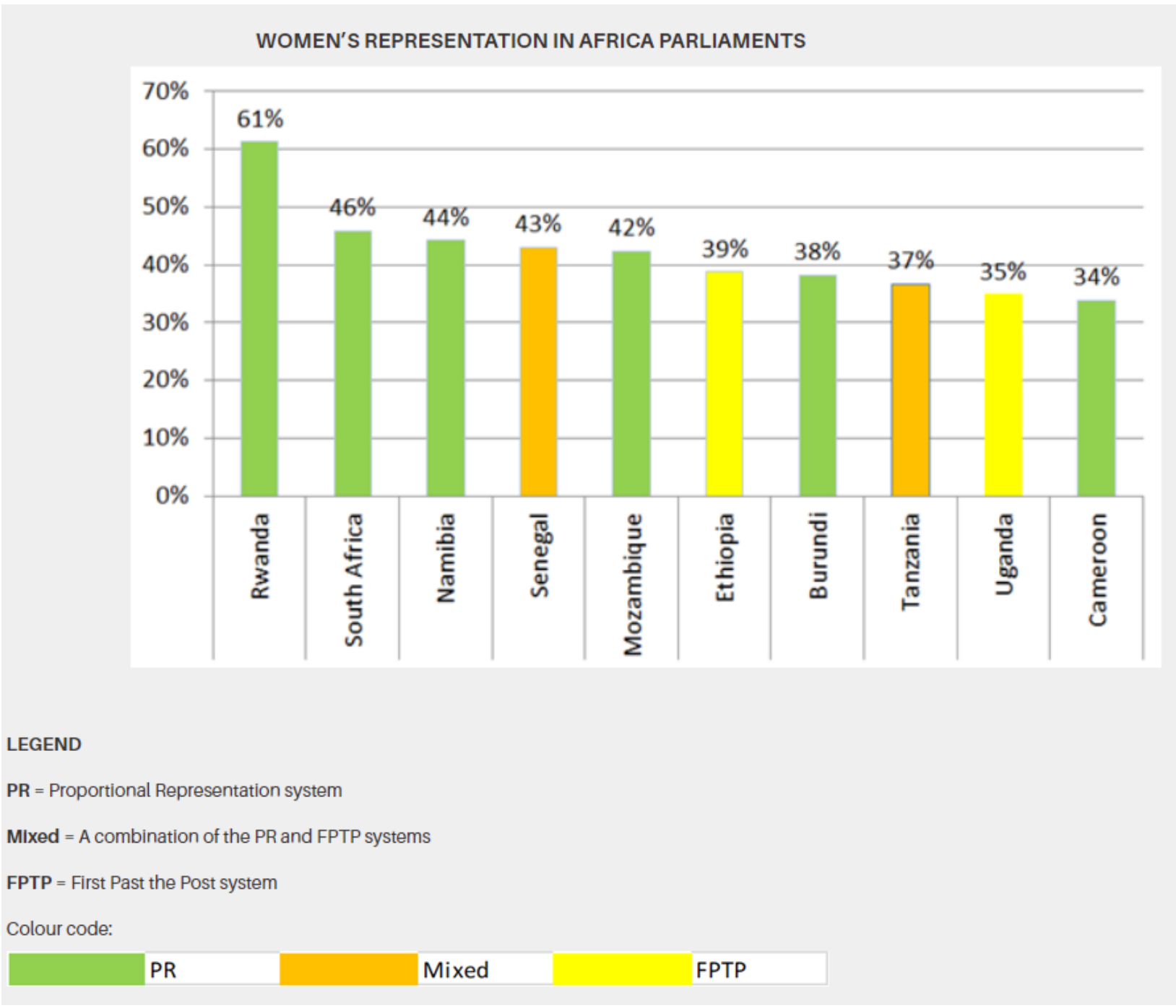

The graph above shows that proportionally, Rwanda has the highest representational system while Cameroon is the lowest. The Africa Barometer published in the year 2021 is a wake-up call that there is a huge amount of work to be done to achieve gender equality in African political institutions (Banda, 2021). In Africa, the under-representation of women in politics is facilitated by several obstacles which are political, socio-economic, ideological and psychological. 


\section{Women Political Participation in Nigeria and Ghana}

In Nigeria, approximately $51 \%$ of women participate in election voting. Despite this, women continue to be underrepresented in elected and appointed roles. According to available data, Nigeria's entire political representation in government is less than 7\%. (Agbalajobi, 2018). This demonstrates that Nigeria has not met the Beijing Platform of Action's requirement of 30\% affirmative votes. Women's participation in elective and appointive roles in Nigeria has been minimal, which is causing concern among many Nigerians. Government and nongovernmental organizations, on the other hand, have undertaken concerted attempts to promote women's political engagement, in line with the declaration issued at the fourth World Conference on Women in Beijing, which advocated for 30 percent affirmative action.

In Nigeria, however, the current National Gender Policy (NGP) proposed 35 percent affirmative action and a more inclusive representation of women with at least 35 percent of elective political and appointive public sector jobs. The patriarchal practices inherent in our society, much of which were seen from the pre-colonial era till today, contributed to women's underrepresentation in political engagement. However, the re-introduction of democratic governance has witnessed once again, an increase in women political participation in elective and appointive offices in Nigeria.

Women have contributed as much to Ghana's advancement, development, and government as men, according to Musa and Gariba (2013). The problem today is that, while accounting for the majority of Ghana's population, women are still underrepresented in politics. Despite this, women in pre-colonial traditional society contributed in a variety of ways, including providing nursing services such as treating injured soldiers' wounds and delivering weapons and water to the warriors. Women lead men to conflicts by mobilizing and organizing them.

\section{Theoretical framework}

The theoretical framework employed for this study is Kanter's "Glass-Ceiling Theory" (1977). The primary focus of this theory is on how the system of work organizations, especially those with a large proportion of white-collar workers, establish women in subordinate positions, that is; they put a 'glass-ceiling' over the opportunities of women (Kanter, 1977). The key political positions in the political system of Nigeria and Ghana can be related to the organization referred to in Kanter's theory.

\section{Methodology}

To undertake a comparative analysis of women's involvement in politics in Nigeria and Ghana, the researcher relied entirely on secondary data. Therefore, this study relied on the use of documentary research design to carry out this study. Data for the study were extracted from political reports, Worldbank, World Development Index (WDI) and selected NonGovernmental Organizations in Nigeria and Ghana.

\section{Recommendation and Conclusion}

Women's political participation in Nigeria and Ghana is a hot topic. Despite the tremendous effort put forth by the government and non-governmental organizations in response to the declaration made at the fourth World Conference on Women in Beijing, which advocated 30 percent affirmative action and the National Gender Policy (NGP) recommendation of 35 
percent affirmative action for a more inclusive representation of women in elective and appointive positions, women have been relegated to the background in politics. It is worth noting that Ghanaian and Nigerian women are still disenfranchised as a result of the country's leadership style. Despite the difficulties women face, women's activism and advocacy, women's education, successive governments' commitment to women's empowerment, and women's desire to participate in politics are all receiving a lot of positive energy. This indicates that women's political participation has a promising future. As a result, key stakeholders should campaign for the protection of women from abuse, economic and political empowerment, and a review of essential legislation to suit the increased interest of women in politics, both elected and appointive roles. The study, therefore, recommends that:

1. Political parties in Nigeria and Ghana should establish a support network for aspiring female politicians by pairing them with experienced female politicians who will serve as mentors and provide capacity building for young or aspiring female politicians in order to enhance and develop them ahead of future elections.

2. To develop an environment that empowers African women to participate actively in decision-making sustainably and effectively that is free of all forms of violence and harassment.

3. Introducing a quota system at all levels of government, as well as identifying and engaging important players such as the Independent National Electoral Commission and political parties to ensure strict compliance.

\section{REFERENCES}

Adeleke J.O (2014). Women's political participation at the local government level: a case study of Akoko South West local government area, Ondo State, Nigeria

Aluko, Y.A (2011). Gender and women's political leadership in Nigeria social and governance policy research development Nigerian institution of social for economic research (NISEN) Ojoo Ibadan, Nigeria httpsllwwwlreseachgate.netlpublic28042364.

Childs, S. \& Krook, M. K. (2008). Critical Mass Theory and Women's Political Representation. Political Studies 56(3) 725-736.

Desa, U. N. (2016). Transforming our world: The 2030 agenda for sustainable development.

Hamah, V. (2015). Women's Participation in Ghanaian Politics: An Assessment of the Opportunities and Limitations. Ghana Center for Democratic Development (CDDGHANA) Briefing Paper, 8(4), 56-74.

Heywood, A. (2011). Global Politics. New York: Palgrave Macmillan

Moshood, K.L., Oladele, T.O., Olakunle, A.A (2019). Women participation and political leadership in Africa: A case of Nigeria. Journal of Research in Humanities and Social Science. 7(4), 49-57.

Musah, B. I., \& Gariba, I. (2013). Women and Political Decision Making: Perspectives from Ghana's Parliament. Journal of Alternative Perspectives in the Social Sciences, 5(3).

Paxton, P., Hughes M. M. \& Green J. L. (2006). The International Women's Movement and Women's Political Representation, 1993-2003. American Sociological Review 71: 898920 . 